\title{
PENGARUH DOSIS PUPUK MAJEMUK NPK (16:16:16) DAN KLON TERHADAP PERTUMBUHAN DAN HASILTANAMAN \\ KAKAO (Theobroma cacao L.)
}

\section{THE EFFECT OF NPK COMPOUND FERTILIZER (16:16:16) AND CLONES TO THE GROWTH AND RESULTS OF COCOA PLANT (Theobroma cacao L.)}

\author{
Winson Hotmawan Saragih ${ }^{1}$, Rusdi Evizal ${ }^{2}$, Hidayat Pujisiswanto², Sugiatno ${ }^{2}$ \\ 1. Jurusan Agroteknologi Fakultas Pertanian Universitas Lampung \\ 2. Dosen Jurusan Agroteknologi Fakultas Pertanian Universitas Lampung \\ Email:winsonturnip@gmail.com
}

\begin{abstract}
Lampung Province is the third largest producer of cocoa beans in Sumatra after West Sumatra and Aceh with 22,067 tons of production and $897 \mathrm{~kg} / \mathrm{ha}$ of productivity in 2013. Almost all (94\%) of the cocoa plantations in Lampung are owned by smallholder with low production. This study aims to determine the effect and interactions of clones and doses on the growth and yield of cocoa. Research was conducted in Sinar Dua village, Way Ratai, Pesawaran and held in December 2018 to May 2019. This research used a split-plot design consisting of two factors. The first factor is cocoa clones placed in the Main Plot, namely Sul 1, Sul 2, ICCRI 3, and MCC 1. The second factor is NPK fertilizer dosage placed on Sub Plot, the dosages are 400, 800, and $1200 \mathrm{~g} /$ tree. The study consisted of 12 treatments and 3 replications, with 36 sampel units in total. Homogeneity of data was tested using the barltlett test then continued with variance and the smallest significant difference test at a 5\% confidence level. The results showed that Sul 1, ICCRI 3, and MCC 1 clones had the highest percent of leaf flush. MCC 1 clone has the highest yield of 4,33 ripe fruits/tree. The NPK compound fertilizer with the dosage of $1200 \mathrm{~g} /$ tree has the highest percent of leaf flush, which is $62,5 \%$ and the dosage of $800 \mathrm{~g} /$ tree has the highest ripe fruit with 4,33 fruit/tree. Sul 1 clone with NPK $800 \mathrm{~g} /$ tree compound fertilizer has the highest number of leaves with 37,3 leaves. MCC 1 clone with NPK $1200 \mathrm{~g} /$ tree compound fertilizer produced the highest dry seed weight per fruit with $77,5 \mathrm{~g} /$ fruit.
\end{abstract}

Keywords: Clone, cocoa, dosage, fertilizer

\section{ABSTRAK}

Provinsi Lampung merupakan daerah penghasil biji kakao rakyat terbesar ketiga di Pulau Sumatera setelah Sumatera Barat dan Aceh dengan produksi dan produktivitas masing-masing sebanyak 22.067 ton dan $897 \mathrm{~kg} /$ ha pada tahun 2013. Hampir keseluruhan (94\%) perkebunan kakao di daerah Lampung merupakan milik rakyat dan berproduksi rendah. Penelitian ini bertujuan untuk mengetahui pengaruh dan interaksi klon dan dosis terhadap pertumbuhan dan hasil kakao. Penelitian dilakukan di Desa Sinar Dua, Kecamatan Way Ratai Pesawaran dan dilaksanakan bulan Desember 2018 sampai Mei 2019. Penelitian menggunakan Rancangan Petak Terbagi yang terdiri dari dua faktor. Faktor pertama klon kakao yang diletakkan pada Petak Utama, yaitu klon Sul 1, Sul 2, ICCRI 3, dan MCC 1. Faktor kedua dosis pupuk NPK yang diletakkan pada Anak Petak, yaitu 400, 800, dan 
$1200 \mathrm{~g}$ /pohon. Penelitian terdiri dari 12 perlakuan dan 3 ulangan, diperoleh total 36 satuan percobaan. Homogenitas data di uji menggunakan uji barltlett kemudian dilanjutkan sidik ragam dan uji beda nyata terkecil pada taraf kepercayaan 5\%. Hasil penelitian menunjukkan klon Sul1, ICCRI 3, dan MCC 1 memiliki pertumbuhan persen flush daun tertinggi. Klon MCC 1 memiliki hasil buah masak tertinggi, yaitu 4,33 buah/pohon. Dosis pupuk majemuk NPK $1200 \mathrm{~g} /$ pohon memiliki persen flus daun tertinggi, yaitu 62,5\% dan $800 \mathrm{~g} /$ pohon memiliki hasil buah masak tertinggi 4,33 buah/pohon. Klon Sul 1 dengan dosis pupuk majemuk NPK 800 g/pohon memiliki jumlah daun tertinggi mencapai 37,3 helai daun. Klon MCC 1 dengan dosis pupuk majemuk NPK $1200 \mathrm{~g} /$ pohon menghasilkan bobot biji kering per buah tertinggi mencapai 77,5 g/buah.

Kata Kunci : Dosis, kakao, klon, pupuk

\section{PENDAHULUAN}

Indonesia merupakan negara penghasil biji kakao terbesar ketiga di dunia setelah Pantai Gading dan Ghana serta peringkat pertama di Asia dengan kontribusi produksinya mencapai 9,28\%. Tahun 2014 indonesia memiliki produksi biji kakao mencapai 350.000 ton (International Cocoa Organization, 2014). Salah satu daerah penghasil biji kakao di Indonesia adalah Provinsi Lampung. Provinsi ini merupakan daerah penghasil biji kakao rakyat terbesar ketiga di Pulau Sumatera setelah Sumatera Barat dan Aceh dengan produksi dan produktivitas masing-masing sebanyak 22.067 ton dan $897 \mathrm{~kg} /$ ha pada tahun 2013 . Hampir keseluruhan (94\%) perkebunan kakao di daerah Lampung merupakan milik rakyat (Direktorat Jenderal Perkebunan, 2015).

Untuk meningkatkan produksi dan mutu biji kakao khususnya di perkebunan rakyat diperlukan bahan tanaman berupa varietas/klon unggul yang mempunyai potensi daya hasil tinggi, kualitas biji yang bermutu tinggi, lebih tahan terhadap serangan hama Penggerek Buah Kakao (PBK) dan patogen busuk buah kakao yang disebabkan oleh Phytophthora palmivora (Evizal, dkk., 2018) dan VSD (Oncobasidium theobromae). Hingga saat ini, ada banyak varietas/klon kakao yang digunakan oleh petani seperti klon kakao mulia seperti ICCRI 1, ICCRI 2, DR 1, DR 2, DR 38, dan DRC 16 dan klon kakao lindak seperti ICCRI 3, ICCRI 4, Sulawesi 1, dan Sulawesi 2 yang memiliki potensi produksi berkisar 1,52 ton/ ha/tahun biji kering (Dibyo dan Edi, 2015; Evizal, dkk., 2016).

Hal lain yang dibutuhkan untuk peningkatan produksi kakao adalah pemupukan. Pemupukan merupakan salah satu kegiatan pemeliharaan tanaman yang berperan penting terhadap produktivitas tanaman kakao. Jika pemupukan yang tidak tepat, lahan kakao akan mengalami kemunduran, khususnya dalam hal kualitas lahan. Berkurangnya unsur hara dalam tanah disebabkan oleh kegiatan panen, pencucian, denitrifikasi, dan erosi yang terjadi di daerah perakaran tanaman kakao (Hasibuan, 2006). Upaya peningkatan kesuburan tanah dapat dilakukan dengan pemberian pupuk. Pemupukan bertujuan menambah unsur-unsur hara tertentu di dalam tanah yang tidak mencukupi kebutuhan tanaman yang diusahakan. Pemupukan 
tanaman kakao harus diberikan secara efisien. Efisiensi pemupukan adalah perbandingan jumlah pupuk yang diberikan dengan jumlah pupuk yang diserap oleh tanaman. Namun umumnya efisiensi pemupukan pada kakao tergolong rendah. Peningkatan efisiensi pemupukan dapat dilakukan dengan menerapkan prinsip empat T, yaitu: tepat jenis, tepat dosis, tepat cara, dan tepat waktu.

Berdasarkan unsur hara yang dikandungnya, pupuk terdiri dari pupuk tunggal dan pupuk majemuk (Sabiham dkk., 1989). Pupuk tunggal adalah pupuk yang mengandung satu jenis hara tanaman seperti $\mathrm{N}$ atau $\mathrm{P}$ atau $\mathrm{K}$ saja, sedangkan pupuk majemuk adalah pupuk yang mengandung lebih dari satu unsur hara tanaman. Pupuk majemuk yang paling banyak digunakan adalah pupuk NPK yang mengandung unsur hara makro yang penting bagi tanaman. Untuk mengurangi biaya pemupukan, sering digunakan pupuk majemuk sebagai alternatif dari pemakaian pupuk tunggal. Penggunaan pupuk ini selain memberi keuntungan dalam arti mengurangi biaya penaburan, dan biaya penyimpanan, juga penyebaran unsur hara lebih merata (Hasibuan, 2006).

Penelitian ini bertujuan untuk mengetahui pengaruh klon terhadap pertumbuhan dan hasil kakao, mengetahui pengaruh dosis pupuk majemuk NPK terhadap pertumbuhan dan hasil kakao, dan mengetahui interaksi antara klon dan dosis pupuk majemuk NPK terhadap pertumbuhan dan hasil kakao.

\section{BAHAN DAN METODE}

Penelitian ini dilakukan di Desa Sinar Dua, kecamatan Way Ratai Pesawaran dan dilaksanakan pada bulan Desember 2018 sampai Mei 2019. Penelitian ini disusun dalam Rancangan Petak Terbagi (Spil-Plot) terdiri dari dua faktor. Faktor pertama klon kakao yang diletakkan pada Petak Utama, yaitu klon Sul 1, Sul 2, ICCRI 3, dan MCC 1. Kakao yang digunakan pada penelitian berumur enam tahun. Faktor kedua adalah dosis pupuk majemuk NPK yang diletakkan pada Anak Petak, yaitu 400 g/pohon, 800 g/pohon, dan $1200 \mathrm{~g} /$ pohon. Penelitian ini terdiri dari 12 perlakuan dan 3 ulangan, diperoleh total 36 satuan percobaan. Homogenitas data di uji menggunakan uji barltlett kemudian dilanjutkan sidik ragam dan untuk mengetahui perbedaan nilai tengah antara perlakuan digunakan uji beda nyata terkecil pada taraf kepercayaan 5\%. Variabel yang diamati pada penelitian ini adalah flush daun, jumlah bunga pada cabang, jumlah bunga pada batang, jumlah pentil buah pada cabang, jumlah pentil buah pada batang, jumlah buah kecil cabang, jumlah buah kecil pada batang, jumlah buah sedang pada cabang, jumlah buah sedang pada batang, jumlah buah besar pada cabang, jumlah buah besar pada batang, jumlah buah masak, jumlah biji per buah, bobot biji kering per buah, dan jumlah biji kering untuk bobot 100 gram.

\section{HASIL DAN PEMBAHASAN}

Hasil penelitian menunjukkan bahwa pertumbuhan vegetatif kakao tertinggi pada 
pengamatan ketiga atau di bulan Februari, sedangkan untuk pertumbuhan generatif atau hasil buah kakao tertinggi pada bulan pengamatan Februari dan April. Hasil analisis data pada penelitian ini memakai satu dari antara enam bulan pengamatan, yaitu dengan cara memilih bulan terbaik yang menghasilkan pertumbuhan dan hasil tertinggi. Dari hasil analisis data menunjukkan bahwa klon dan dosis berpengaruh nyata dan berinteraksi terhadap beberapa variabel pengamatan penelitian .

Hasil penelitian menunjukkan bahwa klon berpengaruh nyata terhadap flush daun, jumlah bunga pada batang, jumlah buah besar pada cabang, jumlah buah masak, jumlah biji kering untuk bobot $100 \mathrm{~g}$, dan bobot biji kering perbuah, sedangkan dosis pupuk NPK berpengaruh nyata terhadap flush daun, jumlah bunga pada cabang dan batang, jumlah buah kecil pada cabang, jumlah buah masak, jumlah biji perbuah, jumlah biji kering untuk bobot $100 \mathrm{~g}$, dan bobot biji kering perbuah. Klon dan dosis pupuk NPK menunjukkan interaksi pada jumlah bunga cabang, jumlah biji perbuah, dan bobot biji kering perbuah.

\section{Pengaruh klon terhadap pertumbuhan dan hasil}

kakao

Hasil penelitian menunjukkan bahwa klon berpengaruh nyata terhadap pertumbuhan flush daun sebagaimana telah dilaporkan oleh Prawoto (2014). Selain itu klon berpengaruh nyata terhadap komponen produksi sebagaimana telah dilaporkan Anita-Sari dan Susuilo (2013). Klon Sul 2 memiliki hasil terendah dibandingkan dengan klon lainnya dengan nilai 47,78\%. Hasil analisis jumlah bunga pada batang menunjukkan bahwa klon MCC 1 memiliki hasil terendah dibandingkan dengan klon lainnya, yaitu 1,44 bunga. Hasil analisis jumlah buah besar pada cabang menunjukkan bahwa klon MCC 1 memiliki hasil tertinggi, yaitu sebanyak 3,44 buah/pohon. Klon Sul 1 menghasilkan jumlah buah besar pada batang tertinggi (1,44 buah) dan klon Sul 2 menghasilkan jumlah buah besar pada batang terendah $(0,33)$. Hasil analisis menunjukkan bahwa klon MCC 1 dan Sul 2 menghasilkan jumlah buah masak tertinggi, yaitu berkisar 3,67-4,33 buah. Hasil analisis jumlah biji kering untuk 100 gram menunjukkan bahwa Sul 2 memiliki hasil tertinggi $(94,44)$ (Tabel 2.)

Tabel 1. Pengaruh klon terhadap flush daun, jumlah bunga pada batang, jumlah buah besar pada cabang, jumlah buah besar pada batang, jumlah buah masak, dan jumlah biji kering untuk berat 100 gram.

\begin{tabular}{ccccccc}
\hline Klon & Flush Daun & $\begin{array}{c}\text { Jumlah bunga } \\
\text { pada batang }\end{array}$ & $\begin{array}{c}\text { Jumlah buah besar } \\
\text { pada cabang }\end{array}$ & $\begin{array}{c}\text { Jumlah buah besar } \\
\text { pada batang }\end{array}$ & $\begin{array}{c}\text { Jumlah buah } \\
\text { masak }\end{array}$ & $\begin{array}{c}\text { Jumlah biji kering } \\
\text { untuk berat } 100 \text { gram }\end{array}$ \\
\hline Sul 1 & $53,9 \mathrm{a}$ & $3,3 \mathrm{a}$ & $1,3 \mathrm{~b}$ & $1,4 \mathrm{a}$ & $1,2 \mathrm{~b}$ & $88,4 \mathrm{~b}$ \\
Sul 2 & $47,8 \mathrm{~b}$ & $3,6 \mathrm{a}$ & $1,0 \mathrm{~b}$ & $0,3 \mathrm{~b}$ & $3,7 \mathrm{a}$ & $94,4 \mathrm{a}$ \\
ICCRI 3 & $55,6 \mathrm{a}$ & $4,1 \mathrm{a}$ & $1,4 \mathrm{~b}$ & $0,9 \mathrm{ab}$ & $0,9 \mathrm{~b}$ & $75,6 \mathrm{c}$ \\
MCC 1 & $54,4 \mathrm{a}$ & $1,4 \mathrm{~b}$ & $3,4 \mathrm{a}$ & $1,1 \mathrm{ab}$ & $4,3 \mathrm{a}$ & $55,8 \mathrm{~d}$ \\
\hline BNT 5\% & 4,7 & 1,5 & 1,5 & 1,1 & 1,4 & 2,8 \\
\hline
\end{tabular}

Keterangan : angka-angka yang diikuti huruf yang sama pada kolom yang sama tidak berbeda nyata pada taraf $5 \%$ 
Tabel 2. Pengaruh dosis pupuk NPK terhadap flush daun, jumlah bunga pada batang, jumlah pentil buah pada cabang, jumkah buah kecil pada cabang, jumlah buah sedang pada batang, jumlah buah masak, jumlah biji kering untuk berat 100 gram

\begin{tabular}{lccccccc}
\hline \multirow{2}{*}{ Dosis } & $\begin{array}{c}\text { Flush } \\
\text { Daun }\end{array}$ & $\begin{array}{c}\text { Jumlah bunga } \\
\text { pada batang }\end{array}$ & $\begin{array}{c}\text { Jumlah pentil } \\
\text { buah pada cabang }\end{array}$ & $\begin{array}{c}\text { Jumlah buah kecil } \\
\text { pada cabang }\end{array}$ & $\begin{array}{c}\text { Jumlah buah sedang } \\
\text { pada batang }\end{array}$ & $\begin{array}{c}\text { Jumlah } \\
\text { buah masak }\end{array}$ & $\begin{array}{c}\text { Jumlah biji kering } \\
\text { untuk berat 100 gram }\end{array}$ \\
\hline $400 \mathrm{~g} /$ pohon & $43,7 \mathrm{c}$ & $1,7 \mathrm{c}$ & $0,7 \mathrm{~b}$ & $0,9 \mathrm{~b}$ & $0,7 \mathrm{~b}$ & $1,3 \mathrm{~b}$ & $80,0 \mathrm{a}$ \\
$800 \mathrm{~g} /$ pohon & $52,5 \mathrm{~b}$ & $3,1 \mathrm{~b}$ & $0,6 \mathrm{~b}$ & $2,5 \mathrm{a}$ & $0,7 \mathrm{~b}$ & $4,3 \mathrm{a}$ & $78,5 \mathrm{~b}$ \\
$1200 \mathrm{~g}$ /pohon & $64,5 \mathrm{a}$ & $4,5 \mathrm{a}$ & $1,6 \mathrm{a}$ & $1,3 \mathrm{~b}$ & $2,1 \mathrm{a}$ & $1,9 \mathrm{~b}$ & $77,2 \mathrm{c}$ \\
\hline BNT5\% & 3,5 & 1,1 & 0,8 & 0,9 & 0,9 & 2,0 & 1,9 \\
\hline
\end{tabular}

Keterangan : angka-angka yang diikuti huruf yang sama pada kolom yang sama tidak berbeda nyata pada taraf 5\%

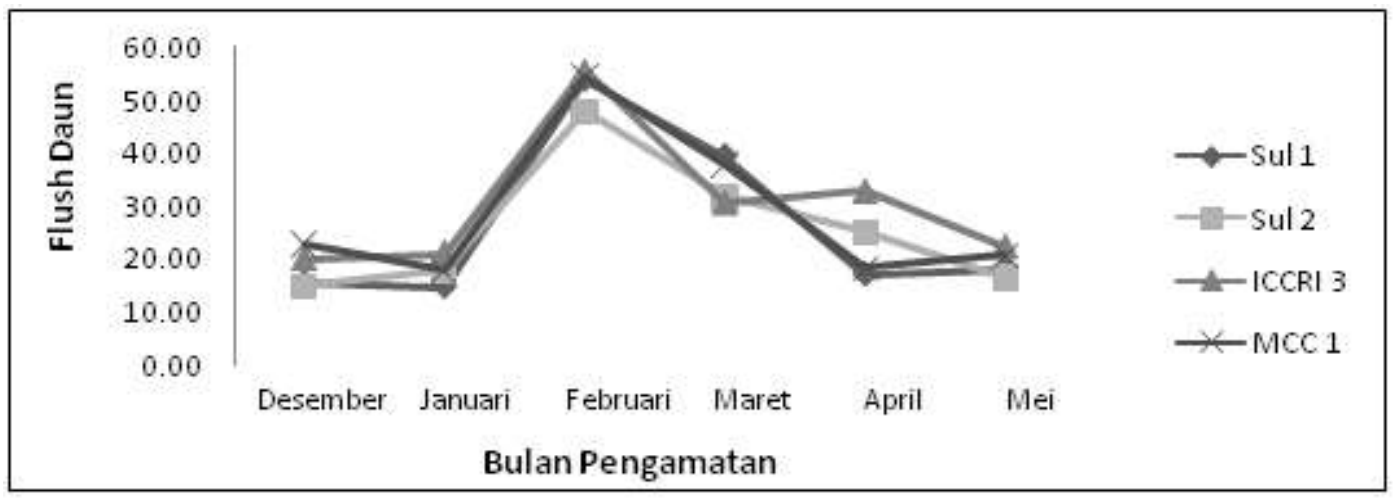

Gambar 1. Pertumbuhan flus daun pada klon kakao selama enam bulan

Hasil analisis menunjukkan bahwa klon berpengaruh nyata terhadap jumlah buah besar pada cabang. Klon MCC 1 menghasilkan jumlah buah besar pada cabang terbanyak, yaitu sebanyak 3,4 buah/ pohon. Hasil penelitian ini juga sesuai dengan data Pusat Penelitian Kopi dan Kakao Indonesia (2016), bahwa klon MCC 1 dapat menghasilkan produksi mencapai 3,67 ton/ha/thn, sedangkan klon Sul 1 dan Sul 2 memiliki produksi berkisar 1,8-2,5 t/ha/thn dan ICCRI 3 hanya mencapai 2,06 t/ha/tahun. Hasil penelitian menunjukkan bahwa klon berpengaruh nyata terhadap jumlah biji kering per 100 gram. Klon Sul 2 memiliki hasil tertinggi dengan menghasilkan 94,4 biji/ 100 gram. Tetapi hasil yang diinginkan adalah jumlah biji yang sedikit untuk bobot 100 gram, dikarenakan semakin sedikit jumlah biji yang dibutuhkan untuk 100 gram maka semakin berat dan besar pula berat biji kering kakao. Sehingga klon MCC 1 yang memiliki hasil terbaik yang hanya membutuhkan 55,8 biji/100 gram. Hal ini sesuai dengan data Pusat Penelitian Kopi dan Kakao Indonesia (2016), klon MCC 1 memiliki berat biji kering 1,7 g/biji. Sedangkan klon Sul 1 berat biji keringnya 1,1 g/biji, Sul 2 dan ICCRI 2 memiliki berat biji kering 1,3 g/biji.

Hasil penelitian selama enam bulan menunjukkan bahwa semua klon memiliki flush daun tertinggi pada pengamatan ketiga yaitu pada bulan Februari (Gambar 1). Hasil penelitian menunjukkan 
bahwa dinamika jumlah buah masak dipengaruhi oleh jenis klon dan bulan pengamatan, yaitu pada pengamatan bulan April menghasilkan jumlah buah masak tertinggi dibandingkan dengan bulan sebelumnya. Selama enam bulan penelitian Sul 2 hanya pada bulan April menghasilkan buah masak sedangkan dibulan lainnya tidak menghasilkan buah masak sama sekali (Gambar 2).

Pengaruh dosis terhadap pertumbuhan dan hasil tanaman kakao

Hasil penelitian menunjukkan bahwa dosis pupuk majemuk NPK berpengaruh nyata terhadap pertumbuhan dan produksi kakao. Hasil analisis menunjukkan bahwa dosis pupuk berpengaruh nyata terhadap flush daun, jumlah bunga batang, jumlah pentil cabang, dan jumlah buah sedang pada batang. Dosis NPK 1200 g/pohon memiliki hasil tertinggi untuk keempat variabel tersebut (Tabel 2.). Hal ini dikarenakan pertumbuhan dan produksi tanaman kakao membutuhkan nutrisi atau unsur hara yang cukup terutama unsur hara N,P, dan K. Menurut Kakao Indonesia (2014), pupuk urea dan NPK memungkinkan perkembangan akar dan ketahanan, serta memacu pertumbuhan vegetatif baru dan produksi bunga. Pemakaian pupuk kimia sebaiknya pada akhir periode panen untuk memacu pembungaan. Pupuk majemuk NPK membantu tanaman dewasa untuk memasok nutrisi pada buah muda dan menunjang perkembangan buah sampai masak. Variabel jumlah buah kecil pada cabang dan jumlah buah masak menunjukkan bahwa dosis pupuk berpengaruh nyata. Dosis NPK $800 \mathrm{~g} /$ pohon memiliki hasil tertinggi untuk kedua variabel tersebut. Hasil ini sesuai dengan penelitian Syukur (2016), menyebutkan bahwa dosis rekomendasi pupuk NPK untuk tanaman kakao berumur lebih dari 4 tahun adalah urea sebanyak 220 g/pohon, TSP sebanyak $180 \mathrm{~g} /$ pohon, $\mathrm{KCl}$ sebanyak $170 \mathrm{~g} /$ pohon, dan Kieserit $115 \mathrm{~g} /$ pohon.

Hasil penelitian selama enam bulan menunjukkan bahwa jumlah buah masak dipengaruhi oleh dosis pupuk dan bulan pengamatan, yaitu di bulan April menghasilkan jumlah buah masak terbanyak dibandingkan bulan lainnya (Gambar 3). Hasil analisis menunjukkan bahwa klon dan dosis berinteraksi

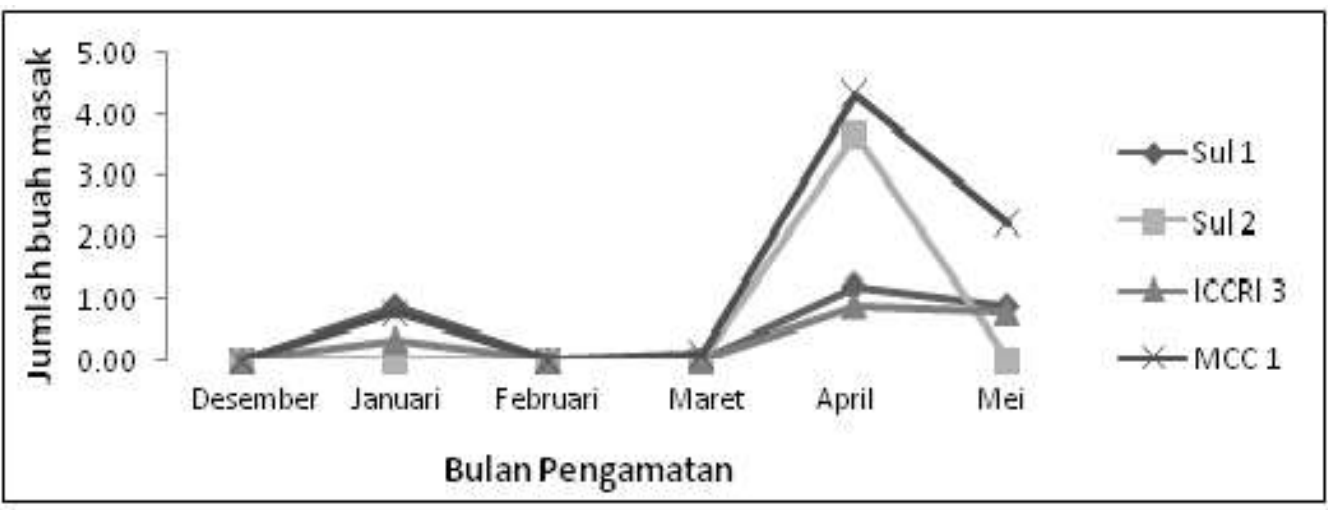

Gambar 2. Jumlah buah masak pada setiap klon selama enam bulan 
Tabel 3. Interaksi pengaruh klon dan dosis pupuk NPK terhadap jumlah daun kakao pada pengamatan bulan Februari2019 (3 bulan setelah aplikasi)

\begin{tabular}{cccc}
\hline Perlakuan & \multicolumn{3}{c}{ Dosis Pupuk Majemuk NPK } \\
\hline Klon & $400 \mathrm{~g} /$ pohon & $800 \mathrm{~g} /$ pohon & $1200 \mathrm{~g} /$ pohon \\
\hline Sul 1 & $34,7 \mathrm{a}$ & $37,3 \mathrm{a}$ & $37,0 \mathrm{a}$ \\
& $(\mathrm{b})$ & $(\mathrm{a})$ & $(\mathrm{a})$ \\
Sul 2 & $35,0 \mathrm{a}$ & $32,7 \mathrm{c}$ & $31,0 \mathrm{c}$ \\
& $(\mathrm{a})$ & $(\mathrm{b})$ & $(\mathrm{b})$ \\
ICCRI 3 & $33,3 \mathrm{a}$ & $33,7 \mathrm{bc}$ & $34,3 \mathrm{~b}$ \\
& $(\mathrm{a})$ & $(\mathrm{a})$ & $(\mathrm{a})$ \\
MCC 1 & $35,0 \mathrm{a}$ & $35,0 \mathrm{~b}$ & $30,3 \mathrm{~d}$ \\
& $(\mathrm{a})$ & $(\mathrm{a})$ & $(\mathrm{b})$ \\
\hline BNT 5\% & & 2,0 & \\
\hline
\end{tabular}

Keterangan:

* Huruf dalam kurung dibaca secara horizontal, membandingkan 3 dosis pada klon yang sama

** Huruf kecil tanpa kurung dibaca vertikal, membandingkan 4 klon pada dosis yang sama

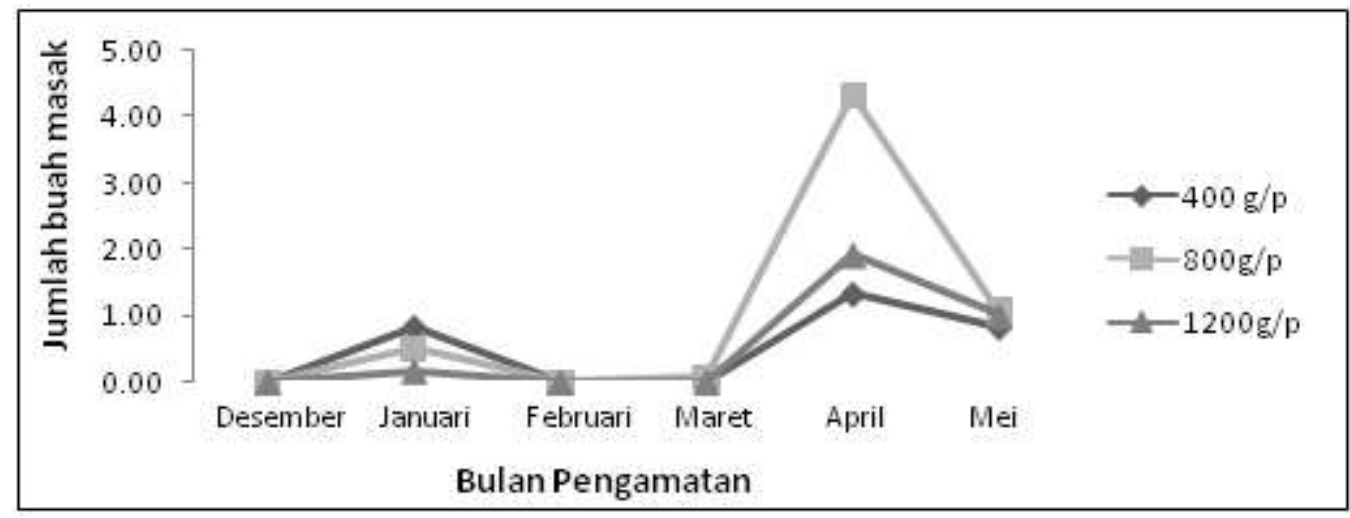

Gambar 3. Jumlah buah masak pada perlakuan dosis pupuk majemuk NPK selama enam bulan pengamatan.

terhadap jumlah daun. Klon dengan dosis NPK400 g/ pohon tidak berpengaruh nyata terhadap jumlah daun, sedangkan klon dengan dosis NPK 800 dan $1200 \mathrm{~g} /$ pohon berpengaruh nyata terhadap pertumbuhan jumlah daun. Klon Sul 1 memiliki jumlah daun tertinggi pada perlakuan dosis NPK 800 dan $1200 \mathrm{~g} /$ pohon (Tabel 3).

Hasil analisis menunjukkan bahwa klon dan dosis pupuk berinteraksi terhadap bobot biji kering per buah. Semua perlakuan klon dengan dosis 400, 800, dan $1200 \mathrm{~g} /$ pohon berpengaruh nyata terhadap bobot biji kering per buah. Klon MCC 1 memiliki berat biji kering perbuah tertinggi pada setiap perlakuan dosis pupuk majemuk NPK. Klon Sul 1, Sul 2, ICCRI 3, dan MCC 1 memiliki bobot biji kering per buah tertinggi pada dosis NPK $1200 \mathrm{~g} /$ pohon (Tabel 4.)

Klon MCC 1 memiliki bobot per buah tertinggi dibandingkan dengan empat klon lainnya pada pemupukan NPK 400, 800, $1200 \mathrm{~g} /$ pohon. Hal ini sesuai dengan pernyataan Pusat Penelitian Kopi dan 
Tabel 4. Interaksi pengaruh klon dan dosis pupuk NPK terhadap bobot biji kering per buah pada tanaman kakao.

\begin{tabular}{cccc}
\hline Perlakuan & \multicolumn{3}{c}{ Dosis Pupuk Majemuk NPK } \\
\hline Klon & $400 \mathrm{~g} /$ pohon & $800 \mathrm{~g} /$ pohon & $1200 \mathrm{~g} /$ pohon \\
\hline Sul 1 & $36,3 \mathrm{c}$ & $41,5 \mathrm{c}$ & $49,2 \mathrm{c}$ \\
& $(\mathrm{c})$ & $(\mathrm{b})$ & $(\mathrm{a})$ \\
Sul 2 & $34,7 \mathrm{~d}$ & $34,7 \mathrm{~d}$ & $37,3 \mathrm{~d}$ \\
& $(\mathrm{~b})$ & $(\mathrm{b})$ & $(\mathrm{a})$ \\
ICCRI 3 & $46,1 \mathrm{~b}$ & $48,1 \mathrm{~b}$ & $54,6 \mathrm{~b}$ \\
& $(\mathrm{c})$ & $(\mathrm{b})$ & $(\mathrm{a})$ \\
MCC 1 & $71,9 \mathrm{a}$ & $74,3 \mathrm{a}$ & $77,5 \mathrm{a}$ \\
& (c) & $(\mathrm{b})$ & $(\mathrm{a})$ \\
\hline BNT 5\% & & 1,8 & \\
\hline
\end{tabular}

Keterangan:

* Huruf dalam kurung dibaca secara horizontal, membandingkan 3 dosis pada klon yang sama

** Huruf kecil tanpa kurung dibaca vertikal, membandingkan 4 klon pada dosis yang sama

Kakao Indonesia (2016), bahwa bobot biji kering klon MCC 1 yaitu 1,75 gram, sedangkan klon Sul 1 memiliki bobot biji kering 1,10 gram, Sul 2 0,75-0,78 gram, dan ICCRI 3 1,27 gram. Penelitian selama enam bulan menunjukkan bahwa pertumbuhan vegetatif kakao memiliki hasil tertinggi di bulan Februari atau tiga bulan setelah pemberian pupuk NPK yang pertama. Sedangkan untuk pertumbuhan bunga, pentil, buah kecil pada bulan Februari sampai Maret dan untuk produksi buah sedang, buah besar, dan buah masak memiliki hasil tertinggi pada bulan April. Hal ini karena pertumbuhan vegetatif diperlukan untuk mendukung pertumbuhan generatif.

\section{KESIMPULAN}

Kesimpulan yang didapatkan dari penelitian ini adalah : 1) Klon dan dosis pupuk majemuk NPK berpengaruh terhadap pertumbuhan dan hasil tanaman kakao. Klon Sul1, ICCRI 3, dan MCC 1 memiliki persen fush daun tertinggi. Klon MCC 1 memiliki hasil buah masak tertinggi, yaitu 4,3 buah/pohon. Dosis pupuk majemuk NPK 1200 g/pohon memiliki persen flus daun tertinggi, yaitu 62,5\%; 2) Dosis pupuk majemuk NPK $800 \mathrm{~g} /$ pohon menghasilkan hasil buah masak tertinggi mencapai 4,3 buah/pohon. Klon dan dosis berinteraksi terhadap pertumbuhan dan produksi kakao, klon Sul 1 dengan dosis pupuk majemuk NPK $800 \mathrm{~g} /$ pohon memiliki hasil jumlah daun tertinggi mencapai 37,3 helai daun; 3) Klon MCC 1 dengan dosis pupuk majemuk NPK 400, 800, dan 1200 g/ pohon menghasilkan bobot biji kering per buah tertinggi, yaitu 71,9 gram, 74,3 gram, dan 77,5 gram.

\section{DAFTAR PUSTAKA}

Anita-Sari, I., dan A. W. Susilo. 2013. Stablitas Karakter Pembungaan, Pertunasan, dan Potensi Jumlah Buah pada 21 Klon Kakao Harapan Koleksi Puslitkoka. Pelita Perkebunan. 29(2): 82-92. 
Dibyo, P. Dan Edi W. 2015. Kompatibilitas Lima Klon Unggul Kakao Sebagai Batang Atas Dengan Batang Bawah Progeni Half-Sib Klon Sulawesi 01. J. Tidp. 3(1) : 29-36.

Direktorat Jenderal Perkebunan. 2015). Statistik Perkebunan Indonesia 2014-2016 Kakao (Vol. 1): Direktorat Jenderal Perkebunan Indonesia. Jakarta.

Evizal, R., Sumaryo, N. Sa'diyah, J. Prasetyo, F. E. Prasmatiwi, dan I. Nurmayasari. 2016. Farm Performance adn Problem Area of Cacao Plantation in Lampung Province, Indonesia. USR International Seminar on Food Security. 1(19): 193-205.

Evizal, R., Sugiatno, Ivayani, H. Pujisiswanto, L. Wibowo, dan F. E. Prasmatiwi. 2018. Incidence Dynamic of Pod Rot Disease of Cocoa Clones in Lampung, Indonesia. J.HPT Tropika. 18(2): 105-111.

Hasibuan. B. E. 2006. Pupuk dan Pemupukan. Departemen Ilmu Tanah, Fakultas Pertanian, Universitas Sumatera Utara. Medan. hal 74.

International Cocoa Organization. 2014. Production of Cocoa Beans Vol. 40 (4) 2014. Avenue Boga Doudou. Abidjan.

Kakao Indonesia. 2014. Panduan dan Cara Budidaya Tanaman Kakao (Theobroma cocoa L.). Indonesia Cocoa and Chocolate. Jakarta. hal 34.

Prawoto, A. A. 2014. Dinamika Pertunasan, Layu Pentil, dan Ketepatan Taksasi Produksi Beberapa Klon Kakao. Pelita Perkebunan. 30(2): 100-114.
Pusat Penelitian Kopi dan Kakao Indonesia. 2016. Klon-Klon Unggul Kakao Lindak. Puslitkoka. Jember. hal 381.

Sabiham, S., G. Supardi, dan S. Djokodudardjo. 1989. Pupuk dan Pemupukan. Fakultas Pertanian, Institut Pertanian Bogor. Bogor.

Syukur. 2016. Modul Pemupukan Kakao. Widyaiswara BPP Jambi. Jambi. hal 62. 